\title{
PENDAMPINGAN KEGIATAN PENDALAMAN KONSEP-KONSEP DASAR FISIKA DAN MATEMATIKA BAGI GURU-GURU ANGGOTA MGMP
}

\author{
Marzuki ${ }^{1 *}$, I Wayan Sudiarta², I Gusti NgurahYudi Handayana ${ }^{3}$, Hiden ${ }^{4}$, Nurul Qomariyah ${ }^{5}$ \\ ${ }_{1 *}, 2,3,4,5$ Program Studi Fisika, Fakultas Matematika dan IImu Pengetahuan Alam, Universitas Mataran \\ Corresponding author: \\ E-mail : marzuki.fis@unram.ac.id
}

Diterima 15 November 2019, Disetujui 19 November 2019

\begin{abstract}
ABSTRAK
Dalam kurun waktu yang cukup lama, bagi sebagian siswa di sekolah beranggapan bahwa pelajaran Fisika dan Matematika merupakan pelajaran yang sulit. Kedua mata pelajaran ini merupakan momok bagi siswa di kebanyakan sekolah, tidak saja di daerah Provinsi Nusa Tenggara Barat (NTB) tetapi juga di berbagai daerah lain di seluruh Indonesia. Untuk itu berbagai upaya perlu dilakukan untuk mengatasi permasalahan kesulitan belajar tersebut. Tidak sedikit guru mengeluhkan rendahnya kemampuan siswanya terutama pada pemahaman konsep-konsep dasar Fisika dan juga Matematika. Ada banyak faktor yang mempengaruhi hal ini, salah satunya adalah faktor input (siswa). Siswa yang berasal dari berbagai sekolah berbeda memiliki tingkat pemahaman yang berbeda pula, baik dalam bidang Fisika maupun Matematika. Atas dasar kondisi yang heterogen inilah penulis mengadakan kegiatan pengabdian masyarakat berupa pemantapan pemahaman konsep-konsep dasar Fisika dan Matematika bagi guru dan juga siswa sebagai bekal awal mereka dalam mengkaji materi selanjutnya secara lebih mendalam, terutama di sekolah luar kota. Kegiatan pengabdian ini dilaksanakan di SMPN 2 Sekotong Lombok Barat. Secara umum dapat disimpulkan bahwa kegiatan ini dapat meningkatkan pemahaman para guru pada konsep-konsep dasar Fisika maupun Matematika, sehingga diharapkan guru dapat menerapkan pemahamannya itu dalam membelajarkan permasalahan-permasalahan yang lebih kompleks kepada siswanya.
\end{abstract}

Kata kunci: pendampingan, konsep dasar, fisika, matematika, MGMP

\begin{abstract}
In a long period of time, for some students at school assume that physics and mathematics lessons are difficult subjects. Both of these subjects are a scourge for students in most schools, not only in the West Nusa Tenggara Province (NTB) but also in various other regions throughout Indonesia. For this reason, various efforts need to be made to overcome these learning difficulties. Not a few teachers complained about the low ability of their students, especially in understanding the basic concepts of Physics and Mathematics. There are many factors that influence this, one of which is the input factor (students). Students from different schools have different levels of understanding, both in the fields of Physics and Mathematics. On the basis of this heterogeneous condition, the writer conducted community service activities in the form of strengthening understanding of the basic concepts of Physics and Mathematics for teachers and also students as their initial provisions in studying further material in more depth, especially in schools outside the city. This dedication activity was carried out at SMPN 2 Sekotong West Lombok. In general it can be concluded that this activity can increase the understanding of teachers on the basic concepts of Physics and Mathematics, so it is expected that teachers can apply their understanding in learning more complex problems to their students.
\end{abstract}

Keywords: assistance, basic concepts, physics, mathematics, MGMP

\section{PENDAHULUAN}

Pada masa-masa sekarang ini, proses belajarmengajar yang terjadi di sekolah haruslah berubah, dari yang selama ini "memberitahu" menjadi "membantu peserta didik mencari tahu" melalui proses inkuiri ilmiah. Hal ini penting, untuk memberikan pengalaman belajar yang lebih bermakna bagi seluruh peserta didik. Siswa harus dilibatkan secara aktif dalam seluruh rangkaian kegiatan belajar-mengajar. Menurut Sadia (1996), melibatkan siswa secara aktif dalam proses inkuiri ilmiah selama pembelajaran merupakan tuntutan dasar dalam pembelajaran IPA. Begitu pula halnya dalam belajar matematika.

Dalam pembelajaran berbasis inkuiri ilmiah peserta didik diberi kesempatan untuk berlatih menganalisia masalah yang dihadapi, 
mencari informasi yang diperlukan, berlatih bertanya dan mempertanyakan informasi yang dirasakannya masih janggal, untuk akhirnya dapat menyelesaikan masalah yang dihadapi. Peserta didik juga perlu dilatih untuk bekerja dalam tim melalui kegiatan-kegiatan secara berkelompok, sebab banyak pekerjaan sekarang ini yang tidak mungkin dikerjakan sendiri. Melalui kegiatan berkelompok siswa juga diberi kesempatan untuk berlatih berdiskusi, mengemukakan pikirannya secara lisan maupun tertulis. Dalam pembelajaran dengan metode inkuiri ilmiah, siswa diberi kesempatan untuk mengalami proses bagaimana layaknya seorang ilmuan dalam mendapatkan pengetahuan dan memecahkan masalah secara sistematik. Jadi bukan hanya sekedar mengerjakan soal sebagaimana yang terjadi selama ini.

Pembelajaran Fisika dan juga Matematika menekankan pada pemberian pengalaman langsung untuk mengembangkan kompetensi siswa, diarahkan untuk "mencari tahu" dan "berbuat" sehingga dapat membantu siswa untuk memperoleh pemahaman konsep yang diinginkan. Akan sangat memudahkan siswa jika dalam pembelajaran Fisika dan juga Matematika para guru mengajak siswa untuk belajar merumuskan suatu konsep secara induktif berdasarkan fakta-fakta empiris terlebih dahulu melalui metode inkuiri ilmiah.

Dalam proses berinkuiri di sekolah, siswa diharapkan telah memiliki kemampuan dasar yang memadai. Namun kendalanya adalah guru sering dihadapkan dengan rendahnya kemampuan dasar siswa. Tidak sedikit guru (khususnya pada tingkat SMA sederajat) mengeluhkan rendahnya kemampuan siswanya terutama pada pemahaman konsep-konsep dasar IPA (khususnya Fisika) dan Matematika.

Ada banyak faktor yang menyebabkan rendahnya kualitas proses pembelajaran di sekolah. Salah satunya adalah faktor input (siswa). Siswa yang berasal dari berbagai sekolah yang berbeda memiliki tingkat pemahaman berbeda pula, terutama dalam bidang Fisika dan Matematika. Adalah fakta bahwa secara umum siswa tamatan SMP sederajat masih banyak memiliki pemahaman konsep dasar Fisika dan Matematika yang rendah. Terlebih kalau membandingkan antara siswa dari sekolah kota dan luar kota, sekolah negeri dan swasta, memiliki perbedaan kemampuan lulusan yang cukup signifikan.

Berdasarkan pengalaman penulis dalam berbagai pertemuan dengan guru-guru Fisika dan juga Matematika di Provinsi NTB, ditemukan masih banyak guru-guru SMP sederajat yang memiliki pemahaman konsep- konsep dasar Fisika dan Matematika sangat rendah. Terlebih kalau guru -guru itu mengajarnya di sekolah-sekolah yang berada di daerah pinggiran. Tentunya kenyataan ini turut berkontribusi pada rendahnya mutu lulusan SMP/M.Ts., yang merupakan sumber siswa SMA/MA sederajat.

Atas dasar kondisi pelaksanaan pembelajaran yang dikemukakan di atas, penulis mengadakan kegiatan Pengabdian Kepada Masyarakat berupa pemberian pemantapan konsep-konsep dasar Fisika dan Matematika bagi para guru dan juga siswa, di SMPN 2 Sekotong Lombok Barat, sebagai bekal awal mereka untuk mengkaji materi Fisika maupun Matematika pada level yang lebih tinggi.

\section{Rumusan Masalah}

Berpijak pada latar belakang masalah yang telah dijabarkan di atas, diajukan permasalahan dengan rumusan sebagai berikut:

1. Bagaimanakah mengatasi kesulitan belajar siswa di sekolah, terutama dalam bidang Fisika dan Matematika?

2. Bagaimanakah tanggapan guru dan juga siswa tentang kegiatan pemantapan materi yang diberikan oleh tim pengabdian?

\section{Tujuan dan Manfaat}

Tujuan kegiatan pemantapan materi ini adalah untuk memberikan pemahaman yang lebih mendalam bagi para guru dan siswa di SMP2 Sekotong tentang konsep-konsep dasar Fisika dan juga Matematika, sehingga diharapkan dapat mengurangi kesulitan belajar siswa dalam mengkaji materi-materi selanjutnya. Di samping itu juga tujuan lainnya adalah memberikan kiat-kiat belajar Fisika dan Matematika secara mandiri kepada siswa agar lebih mudah memahami konsep, tanpa harus selalu didampingi oleh guru.

Adapun manfaat kegiatan pengabdian ini dilakukan adalah sebagai berikut:

1. Membantu guru-guru dalam menangani kesulitan memberikan pemahaman tentang konsep dasar Fisika dan Matematika.

2. Memberikan kontribusi terhadap sekolah sekolah yang gurunya tergabung dalam MGMP bidang matematika dan fisika dalam upaya peningkatan kualitas pembelajaran Fisika dan Matematika di lingkungan sekolah di Kecamatan Sekotong.

\section{HASIL DAN PEMBAHASAN}

Pemantapan Konsep - Konsep Dasar Fisika Dalam kegiatan pemantapan materi Fisika, materi yang diberikan adalah masalah 
gerak lurus. Alasannya adalah oleh karena masih banyak siswa yang mempelajari konsep dasar ini dengan ketuntasan yang kurang memadai, sehingga di jenjang yang lebih tinggi mereka masih kesulitan memahami materi ini. Atas dasar inilah maka konsep gerak lurus ini menjadi penting untuk didiskusikan oleh para guru di sekolah agar ketuntasan yang diharapkan dapat terpenuhi.

Materi gerak lurus ini hampir dapat dipastikan bahwa guru membelajarkannya di sekolah dengan metode ceramah saja dengan alasan susah mempraktekannya dan memakan waktu yang cukup banyak sekiranya dipraktekkan. Inilah yang menyebabkan siswa kurang memahami konsep dasar ini dengan baik. Mengatasi hal ini ditawarkan suatu solusi yaitu menganalisis tiruan hasil rekaman ticker timer pada pita ketik, dengan memberikan pemahaman terlebih dahulu tentang bagaimana sistem kerja ticker timer sehingga memperoleh hasil pada pita ketik yang akan dianalisis untuk memperoleh informasi tentang konsep gerak lurus.

Melalui pengolahan data hasil analisis tersebut, siswa dapat menggambarkan bagaimana bentuk grafik hubungan posisi terhadap waktu (grafik $x-t$ ), kecepatan terhadap waktu (grafik $v-t$ ), dan percepatan terhadap waktu (grafik $a-t$ ). Kemudian, dengan memberikan beberapa contoh kumpulan data hasil pengamatan yang berbeda-beda mengenai hubungan kecepatan terhadap waktu, siswa dapat membuat grafik hubungan $v$ - $t$ dengan kemiringan yang berbeda-beda. Berdasarkan grafik-grafik tersebut siswa dapat menginterpretasikan besarnya percepatan yang dialami oleh masing-masing benda yang bergerak lurus beraturan maupun yang berubah beraturan, serta dapat membangun pemahaman mereka tentang hubungan antara besar kemiringan grafik dengan besar percepatan benda bahwa:" makin besar kemiringan grafik hubungan $v-t$ suatu gerak benda, berarti makin besar pula percepatannya". Penyelesaian persoalanpersoalan sederhana dapat diberikan kepada siswa untuk meningkatkan pemahaman mereka terhadap konsep gerak lurus berubah beraturan.

Dalam praktek pembelajaran di kelas tentang materi kinematika gerak lurus, umumnya siswa memiliki kesulitan dalam hal: (1) membedakan kecepatan rata-rata dan kelajuan rata-rata-rata, (2) membedakan kecepatan rata-rata dengan kecepatan sesaat, (3) membedakan percepatan rata-rata dengan percepatan sesaat, (4) menggambarkan dengan baik grafik hubungan $x-t$, grafik hubungan $v-t$, dan grafik hubungan $a-t$ dari gerak benda, dan (5) mencari informasi tentang posisi, kecepatan, dan percepatan benda pada saat tertentu melalui grafik yang ada. Kebanyakan siswa juga beranggapan bahwa arah kecepatan selalu sama dengan arah percepatan. Kemampuan matematik yang kurang juga turut menghambat dalam proses pemahaman konsep siswa. Kekurangankekurangan ini harus disadari sedini mungkin oleh guru serta melakukan langkah-langkah antisipasi dengan membuat persiapan yang lebih baik agar memudahkan siswa melakukan proses pemahaman konsep. Untuk itu seorang guru juga dituntut memiliki pemahaman konsep yang baik agar dapat membelajarkan materi kepada siswa dengan lebih optimal. Dengan demikian pembelajaran akan menjadi lebih bermakna (meaningful).
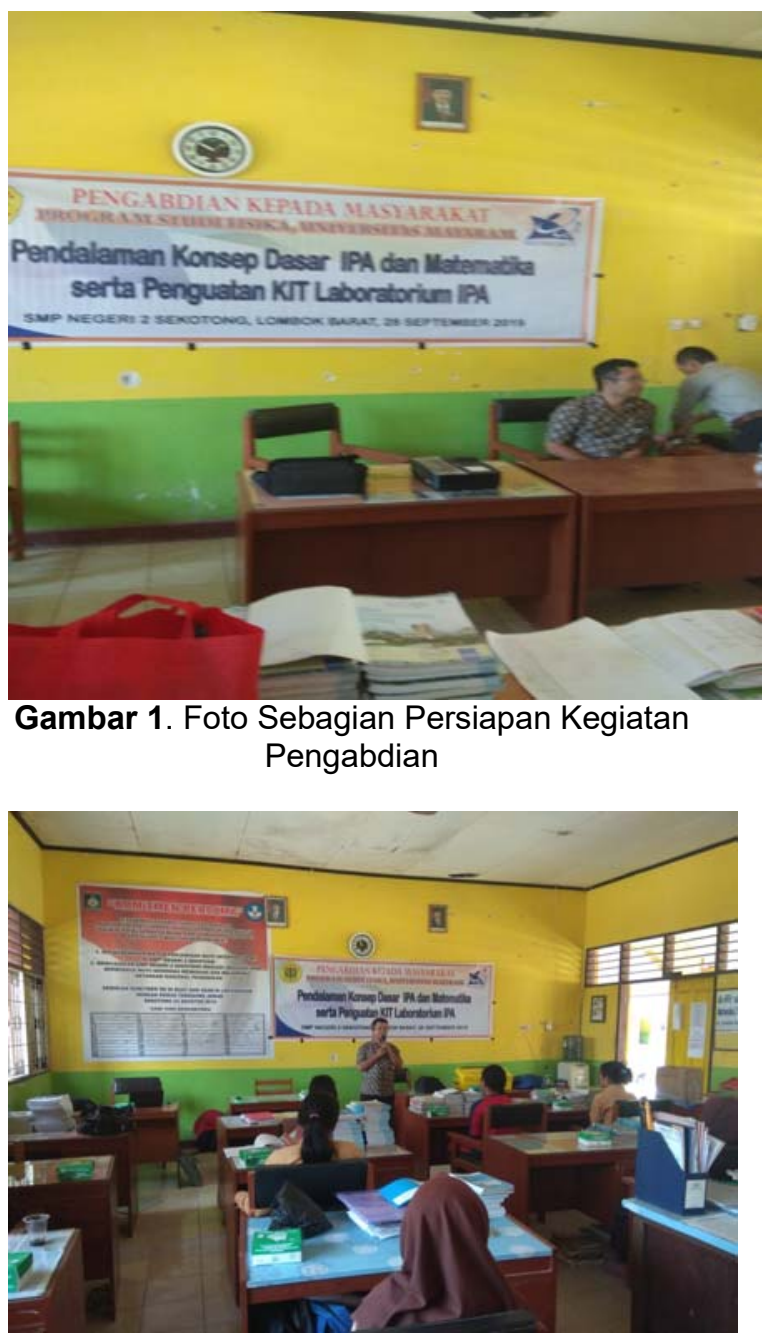

Gambar 2. Foto pembekalan Materi Fisika

\section{Pemantapan Konsep - Konsep Dasar Matematika}

Berdasarkan analisis terhadap hasil pantauan pelaksanaan kegiatan pengabdian, 
didapatkan beberapa fakta bahwa secara umum para guru mengatakan siswanya sudah memiliki pemahaman tentang konsep deret, baik deret aritmetika maupun deret geometri, apabila diberikan sejumlah soal mengenai deret. Akan tetapi, begitu persoalan deret ini divariasikan, mereka tidaklah dengan mudah untuk menyelesaikannya, seperti pada soal materi pengabdian yang diberikan. Pada bagian itulah tim memberikan pemantapan konsep yang lebih mendalam agar pemahaman terutama kepada gurunya dengan berbagai tipe soal, agar nantinya dapat membelajarkannya kepada siswa mengenai konsep ini dengan lebih baik.

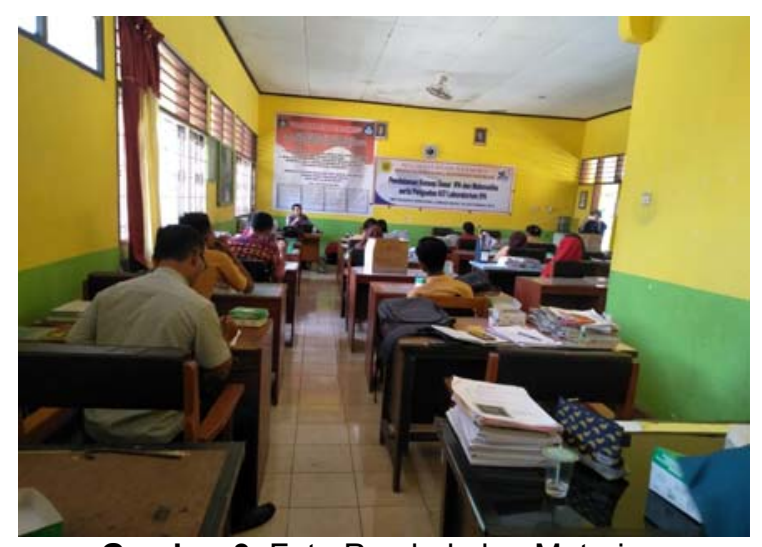

Gambar 3. Foto Pembekalan Materi Matematika

Pemahaman siswa tentang konsep persamaan linier menurut para guru barulah sampai pada memahami bentuk $y=m x+c$. Siswa juga faham bahwa dua buah garis yang sejajar gradien kedua garis tersebut sama $\left(m_{1}=m_{2}\right)$, dan apabila saling tegak lurus maka hasilkali kedua gradien garis tersebut akan memenuhi $m_{1} m_{2}=-1$. Namun demikian, begitu diberikan permasalahan seperti berikut: "Jika garis I dengan persamaan $(x-2 y)+a(x+$ $y)=$ a sejajar dengan garis $g$ dengan persamaan $(5 y-x)+3 a(x+y)=2 a$, tentukan nilai a", mereka mengalami kesulitan memecahkannya.

Pada penyelesaian sistem persamaan linier 3 variabel, guru merasa lebih senang menyelesaikannya dengan menggunakan aturan Cramers setelah tim memperkenalkan cara itu, karena dipandang lebih simpel jika dibandingkan dengan metode lain yang sudah mereka kenal seperti metode substitusi, eliminasi, ataupun metode inversi. Akan tetapi aturan ini belum bias diajarkan kepada siswa SMP karena mereka harus mempelajari tentang matriks dulu, yang mana hal ini beru diberikan di tingkat SMA. Adapun persoalan mengenai materi program linier, kesulitan yang dialami siswa adalah pada saat membuat model matematika dari kalimat matematika yang disodorkan, serta kesulitan dalam menggambarkan grafiknya. Kemampuan ini perlu dilatihkan dengan seksama.

Pembelajaran tentang fungsi, secara umum para guru mengatakan bahwa pemahaman siswa tentang konsep dasar fungsi dapat dikatakan cukup memadai. Akan tetapi pada level yang lebih tinggi, siswa masih kesulitan. Di sinilah tim memberikan kiat-kiat untuk memudahkan guru membelajarkan materi ini.

Pada pemantapan mengenai konsep persamaan kuadrat, siswa tidak mengalami kesulitan dalam mencari titik potong grafik fungsi pada sumbu $X$ ataupun $Y$. Mencari jumlah dan hasilkali akar-akar serta membentuk persamaan kuadrat dari akar-akar yang diberikan juga bukanlah materi yang dianggap sulit. Namun, kesulitan siswa adalah pada saat mereka diminta membuat grafik dari data yang ada, serta membuat persamaan kuadrat dari grafik yang diberikan.

Secara umum kedatangan tim di masyarakat sekolah, khususnya di SMPN 2 Sekotong Lombok Barat, dipandang cukup bermakna terutama dalam memberikan pemahaman yang lebih mendalam tentang konsep-konsep dasar Fisika maupun Matematika.

\section{SIMPULAN DAN SARAN \\ Simpulan}

Berdasarkan keseluruhan uraian yang telah disampaikan, maka beberapa hal yang dapat disimpulkan, antara lain:

1. Kesulitan-kesulitan belajar siswa perlu dideteksi sejak dini agar tidak menimbulkan kesulitan baru yang lebih kompleks pada materi- materi selanjutnya. Mengatasi kesulitan belajar siswa antara lain dapat dilakukan dengan cara memberikan review (pemantapan kembali) konsep-konsep yang dianggap cukup fundamental, terutama dalam bidang Fisika dan Matematika, dengan metode yang lebih variatif.

2. Secara umum para siswa sangat senang dengan kegiatan ini karena banyak mendapatkan cara-cara baru dalam menyelesaikan permasalahan matematika maupun IPA khususnya fisika. Begitupun para guru baik guru matematika maupun fisika cukup senang mengikuti kegiatan semacam ini karena merasa mendapatkan tambahan cara baru dalam membelajarkannya di sekolah.

3. Berbagai alternatif metode pembelajaran atau cara-cara baru dalam membelajarkan suatu materi perlu disebarluaskan dalam 
rangka meningkatkan kualitas pembelajaran di sekolah.

\section{Saran}

Melihat antusiasme para guru dan siswa dalam mengikuti kegiatan pemantapan materi ini serta manfaatnya yang sangat besar terutama dalam meningkatkan tingkat pemahaman siswa, maka diharapkan kegiatan ini memiliki keberlanjutan di masa-masa mendatang. Diharapkan juga kepada pihak lembaga Penelitian dan Pengabdian kepada Masyarakat (LPPM) UNRAM agar mengalokasikan dana yang lebih besar, agar kegiatan ini bisa menjangkau masyarakat yang lebih luas, khususnya masyarakat sekolah. Pemantapan konsepkonsep dasar semacam ini tidak saja dilakukan pada bidang Fisika dan Matematika saja, tetapi juga diharapkan dapat dilakukan dalam bidang yang lainnya, demi tercapainya kualitas pendidikan yang lebih baik, utamanya di daerah Provinsi Nusa Tenggara Barat.

\section{DAFTAR RUJUKAN}

Ahmadi, A. (1997). Strategi Belajar-Mengajar. Bandung : Pustaka Setia

Depdikbud. (2013). Dokumen Kurikulum 2013. Jakarta: Depdikbud.

Rutherford, J. F. \& Ahlgren, A. (1990). Science for All American. New York: Oxford University Press.

Sadia, W. (1996). Pengembangan Program Belajar Konstruktivis dalam Pembelajaran IPA di Sekolah Menengah Pertama (SMP). Disertasi Doktor pada FPS IKIP Bandung: tidak diterbitkan.

Sumaji, dkk. 1998. Pendidikan Sains yang Kumanis. Yoygakarta: Kanisius. 